
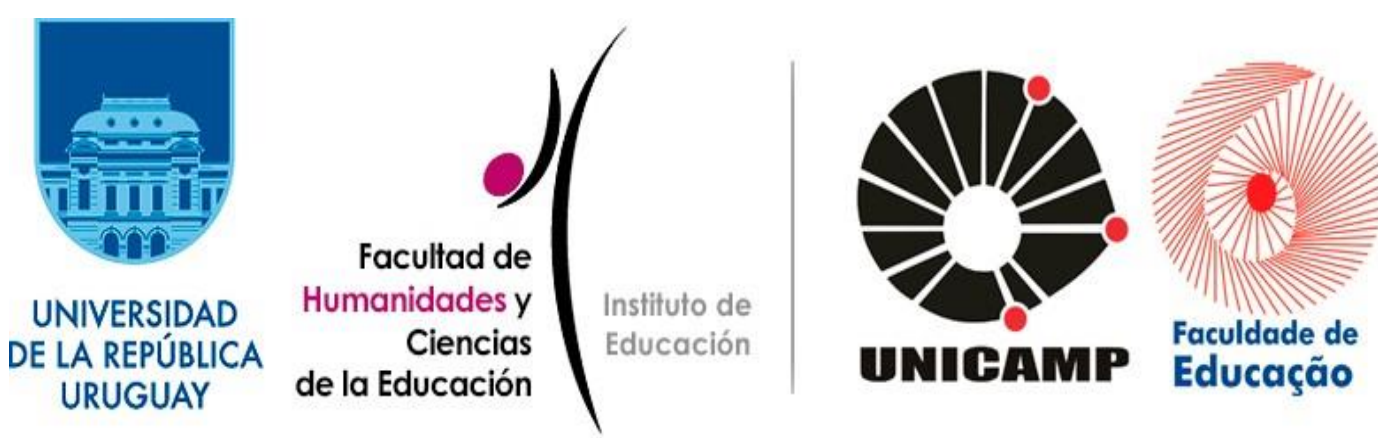

ARTÍCULO | ARTIGO

Fermentario V. 12, № 2 (2018)

ISSN 16886151

Instituto de Educación, Facultad de Humanidades y Ciencias de la Educación,

Universidad de la República. www.fhuce.edu.uy

Faculdade de Educação, UNICAMP. www.fe.unicamp.br

Jurar en la Matriz: El reconocimiento del credo como bandera

católica

Swear in the Matrix: Recognition of the creed as a Catholic flag

Yanelin Brandón García ${ }^{1}$

DOI: https://doi.org/10.47965/fermen.12.2.2

\title{
Resumen
}

El acto público del 19 de junio de 2014 realizado por dos colegios católicos de Montevideo en la catedral metropolitana provocó inquietud en las autoridades del Consejo de Enseñanza Secundaria. A partir del mismo, se inició una investigación administrativa que buscó comprobar el cumplimiento o no de las normas del Estado y de la propia Secundaria en este accionar. Las conmemoraciones oficiales y el acto de Jura de la Bandera deben cumplir con una serie de formalidades estipuladas por la reglamentación que las autoridades competentes deben monitorear.

\footnotetext{
${ }^{1}$ Asistente Departamento de Historia Universal, Facultad de Humanidades y Ciencias de la Educación, UDELAR /Prof. de Historia Medieval y Temprano Moderna en Consejo de Formación en Educación / Prof. de Historia en Enseñanza Secundaria / Diploma en Didáctica en Enseñanza Media, Opción Historia/ Maestranda en Ciencias Humanas, Opción Historia Rioplatense, Email: yanelinb@ hotmail.com
} 
En este caso en particular, el lugar elegido y la presencia activa de la autoridad eclesiástica, fueron detonantes de crítica y generaron la ejecución de los mecanismos de control del Consejo. En este artículo se analizan el marco reglamentario, los informes oficiales y las posturas en prensa generadas en torno al caso.

Palabras clave: Estado, Laicidad, educación, religión

\begin{abstract}
The public act of June 19th 2014, carried out by two Catholic schools in Montevideo in the metropolitan cathedral, provoked concern among the authorities of the Secondary Education Council. From that moment, an administrative investigation was initiated that sought to verify the compliance or not of the norms of the State and of the High school itself in this action. The official commemorations and the act of Jura de la Bandera must comply with a series of formalities stipulated by the regulations that the competent authorities must monitor.

In this particular case, the chosen place and the active presence of the ecclesiastical authority, triggered criticism and generated the execution of the control mechanisms of the Council. This article analyzes the regulatory framework, the official reports and the press positions generated around the case.
\end{abstract}

Keywords: State, Secularity, education, religion

\title{
Introducción
}

En Uruguay la existencia de un Estado laico, separado de cualquier confesión religiosa, constituye un marco legal de gran riqueza expresiva. La laicidad para un uruguayo es parte integral del derecho ciudadano pero como concepto que ha trascendido en el tiempo, ha tenido una naturaleza maleable producto del encuentro y rechazo de diferentes corrientes de pensamiento. Tradicionalmente la laicidad ha sido concebida desde la neutralidad del Estado en materia religiosa, confinando los temas espirituales al ámbito privado tal como se había instrumentado en Francia. Sin embargo, para otros, principalmente para quienes se han vinculado a diversas religiones, el Estado laico constituye una plataforma de pluralismo que permite viabilizar la problematización y el ejercicio de la diversidad en el espacio público bajo el principio de tolerancia. Las raíces de esta última concepción pueden 
encontrarse según el filósofo Edgar Morin, en la primera modernidad europea, siendo un fuerte impulso el movimiento multifacético renacentista, al cual asigna la construcción dialógica de la realidad, del mundo y de sus concepciones ideológicas y trascendentales (Morin, E., 2001: 110). La laicidad estatal quedó consagrada en la segunda Constitución Nacional aprobada en 1917 -que comenzó a regir en 1919- luego de un largo proceso por el cual la iglesia católica fue perdiendo funciones y lugares en los espacios públicos desde la ley de secularización de cementerios en 1861. En materia educativa, los contenidos religiosos fueron abandonándose en la malla curricular desde la reforma valeriana de 1877, teniendo en la ley de 1909 otro hito fundamental de este derrotero al prohibir toda práctica religiosa en cualquier centro de enseñanza bajo la órbita del Estado.

Por su parte, los colegios confesionales continuaron abriendo sus puertas a las familias católicas y se convirtieron en una opción frente a las "escuelas sin Dios" del Estado. Ante éstas debieron competir por los alumnos de los barrios donde se instalaron, mientras que las exigencias del mercado y de las autoridades competentes, los llevaron a tramitar las habilitaciones que acreditaran su nivel académico y la puesta en práctica de las pautas estatales para su funcionamiento. Más allá del cumplimiento de los planes y programas oficiales, se les pautó una serie de reglamentos para el funcionamiento cotidiano de las instituciones y las celebraciones patrióticas que rigieron tanto la enseñanza estatal o "pública" como la "privada", laica o confesional.

La Jura de la Bandera Nacional constituye un acto institucional "público y solemne" impuesto por el art. 28 de la ley $\mathrm{N}^{\circ} 9.943$ del 20 de julio de 1940 para todos los ciudadanos naturales y legales. El mismo establece que las instituciones educativas "dispondrán que en sus respectivos locales los alumnos presten ese juramento en idénticas condiciones". Realizado todos los 19 de junio - según art. 79 del Decreto 886 del 19 de diciembre de 1940-, fecha de nacimiento del prócer nacional José Gervasio Artigas, convoca a realizar la "jura" a todos los alumnos de primer año de Secundaria. El 26 de mayo de 1943 se estipuló por Decreto que el acto debía ser realizado en todos los establecimientos oficiales y habilitados del país.

En 2014 los primeros de liceo de dos colegios católicos de Montevideo de una misma congregación religiosa, realizaron esta celebración en la Iglesia Matriz con el recientemente nombrado Arzobispo de la ciudad Padre Daniel Sturla sdb como testigo de la ceremonia. Al momento de realizar el juramento, la autoridad eclesiástica estuvo encargada de su lectura a solicitud de uno de los directores, siendo éste último el responsable de tomarlo, fórmula que dio al acto validez reglamentaria. 
Varios medios de prensa se hicieron eco de este acto patrio, su difusión disparó el debate acerca del lugar elegido y de la presencia de esta autoridad cristiana. El presente artículo aborda el análisis de este caso en particular y reflexiona sobre las concepciones en torno a la laicidad que pusieron en juego los protagonistas y quienes se manifestaron al respecto. Con este fin, presentamos primeramente las características principales del proceso de secularización en nuestro país y las nociones sobre lo laico que fueron ganando terreno en el debate intelectual de principios del siglo XX.

\section{Perspectivas en torno a la laicidad}

En Uruguay cohabitan pobladores cuyos orígenes pueden remontarse a diversas partes del mundo. Siendo su población el resultado de diferentes corrientes inmigratorias, los mayores flujos de arribo pueden observarse a finales del siglo XIX y principios del XX principalmente llegados desde España e Italia. Si bien no toda población era recibida con el mismo entusiasmo en estas tierras -eran preferidos los occidentales a los pobladores de Europa del Este y Oriente Medio-, la mayor parte de los extranjeros fue asimilando la cultura del país a través de la educación.

En ese período la idea de República se vinculó a la expansión de las funciones del Estado. El mismo fue producto de un largo proceso por el cual se reafirmaron los valores y símbolos civiles con el objetivo de restarle poder político, social y administrativo a la Iglesia Católica. Se fue imponiendo un discurso secularizador por el cual se representaba al país dividido en dos "partidos en conflicto" (categoría de análisis utilizada por Sloterdijk, 2011); por un lado los liberales de tendencia radical y los sectores de izquierda que tenían la neutralidad religiosa como principio, mientras que por otro, se encontraban los católicos -vinculados a los sectores conservadores y liberales moderados de los partidos tradicionales, así como a la Unión Cívica creada en 1911-, que defendían la libertad de expresión de su religión por entender que era la fe de la mayoría de la población.

Esta lucha entre ambas tendencias hizo foco en los espacios públicos como lugar de encuentro común a todo uruguayo, donde el Estado fue asumiendo el específico interés de no mostrar imágenes religiosas que pudieren atentar contra el nuevo principio: la laicidad. Esta postura estatal se vio acompañada de cambios a nivel de la enseñanza, donde se apostó a crear una escuela laica como sinónimo de "neutralidad y casi de obligatoriedad de silencio público con relación a definiciones religiosas" (Caetano, 2013: 370). La gratuidad y la obligatoriedad fueron factores esenciales para extender el poder de convocatoria de la escuela a toda la población, ya que se consideraba que esta institución no podía continuar siendo un lugar de privilegio de unos pocos niños. Estos tres principios básicos fueron insignia del Decreto Ley de Educación Común de 1877 con el que nuestro país 
procuraba flexibilizar las estructuras de pensamiento que consideraba cerradas y dogmáticas, y apostaba al reconocimiento de la existencia de diversos credos y a la libertad en materia religiosa.

El proyecto de José Pedro Varela que daba impulso a la laicidad fue modificado a través del DecretoLey que instituía la enseñanza religiosa no obligatoria para los niños que asistían a la escuela. A propósito, el art. 18 disponía que "la enseñanza de la religión católica es obligatoria en las escuelas del Estado, exceptuándose a los alumnos que profesen otras religiones y cuyos padres, tutores o encargados se opongan a que la reciban" (Greising, en: Caetano, 2013: 242).

En este contexto, la educación se fue convirtiendo en una "zona de lucha ideológica" dado que, determinar los programas y valores morales a impartir en las escuelas estatales y colegios habilitados constituía el nodo fundamental de formación de los futuros ciudadanos libres de todo contenido dogmático -en caso de los colegios confesionales la enseñanza religiosa se fue limitando a Catequesis-. Desde entonces, los cristianos, tanto protestantes como católicos, así como los judíos y quienes profesaran cualquier religión, sólo podían ser reconocidos como tales en la intimidad del hogar así como en aquellas esferas de actividad volcadas a espacios donde la comunidad de fe se reunía y manifestaba, en los templos e instituciones asociadas al credo.

El país había nacido en sus orígenes como Estado confesional católico según su primera Constitución en 1830 pero el sector liderado por José Batlle y Ordóñez del Partido Colorado -de gran anuencia electoral en la capital principalmente-, había luchado por una nueva carta magna que impusiera un Estado laico en conformidad con el despliegue de la libertad de cultos. Esta nueva Constitución producto del acuerdo entre colorados y nacionalistas- entró en vigencia en 1919 y fue el corolario de un proceso de enfrentamientos por la conquista de los lugares considerados del común. El Estado uruguayo no asumía una fe oficial y se disponía a continuar acogiendo en su seno a una población diversa en sus orígenes y en su fe. La separación Estado - Iglesia quedó consagrada tempranamente.

Con el devenir de los años siguientes el modelo de laicidad negativa se fue imponiendo, convirtiéndose en la base de las relaciones entre religión y política, y determinando el lugar de las manifestaciones religiosas en el Uruguay del siglo XX (Caetano y Geymonat, 1997: 47). Las dos instituciones comenzaron a construir una concepción binaria donde el Estado y la iglesia tenían su estructura y pautas de funcionamiento en las que primaba el principio de autonomía con respecto a la otra. En el caso concreto de la educación, fueron generando acuerdos que permitieron el funcionamiento de los colegios confesionales católicos. 
Sin embargo, avanzado el siglo XX, se generaron a nivel mundial una serie de conflictos violentos que plantearon desafíos político-culturales a la convivencia. Los mismos determinaron la aprobación de declaraciones de organismos internacionales que involucraron el derecho a la libertad religiosa y sus manifestaciones públicas, tanto individuales como colectivas. En este sentido, destacamos aquellas realizadas por la Asamblea de la Organización de las Naciones Unidas en materia de expresión religiosa. La Declaración Universal de los Derechos Humanos del 10 de diciembre de 1945 en su art. 18 proclamaba "la libertad de manifestar su religión o su creencia, individual y colectivamente, tanto en público como en privado, por la enseñanza, la práctica, el culto y la observancia”. A esta disposición se sumó la Resolución 36/55 del 25 de noviembre de 1981 por la que se sancionó la Declaración sobre la eliminación de todas las formas de intolerancia y discriminación fundadas en la religión o las convicciones. (González Merlano, 2015: 85 y 95) La aceptación de estos documentos internacionales planteó obligaciones a los Estados que a partir de entonces, debieron velar por su respeto y cumplimiento, y con ello, revisar la normativa vigente al interior de sus estructuras organizativas. El Estado uruguayo fue uno de ellos.

Por su parte, desde la propia iglesia católica se han realizado esfuerzos para proteger las libertades de sus fieles. La Declaración Dignitatis humanae del II Concilio de Vaticano del 7 de setiembre de 1965 expresó la necesidad de establecer la libertad religiosa como derecho civil en el ordenamiento jurídico de las sociedades.

\footnotetext{
Esta libertad consiste en que todos los hombres han de estar inmunes de coacción, tanto por parte de individuos como de grupos sociales y de cualquier potestad humana, y esto de tal manera que, en materia religiosa, ni se obligue a nadie a obrar contra su conciencia, ni se le impida que actúe conforme a ella en privado y en público, sólo o asociado con otros, dentro de los límites debidos. (Concilio Vaticano II, Declaración Dignitatis humanae, 7/9/1965, Cap. I, Inc. 2.)
}

En estos últimos años, las cuestiones religiosas se han abierto camino hacia una notoriedad que recuerda en parte a los tiempos en que detentaban un espacio de privilegio en la cotidianeidad social. Son ejemplo de ello, las discusiones sobre la instalación de símbolos y esculturas religiosas en lugares públicos (la Cruz y la estatua de Juan Pablo II en Tres Cruces), las protestas por la imposibilidad de colocar la imagen de la Virgen María en la rambla capitalina, el empleo de balconeras para recuperar el sentido cristiano de la Navidad, entre otros. Esta apuesta hacia una mayor visibilidad se ha visto reimpulsada por Sturla, quien ya como cardenal, en la homilía del 24 de diciembre de 2016, invitó a los católicos a quitarse el "balde laicista" por el cual entiende que se les ha instruido para que limiten su libertad de conciencia individual al ámbito privado. (Sturla en: aciprensa.com, 10/enero/2017) 
En la actualidad las religiones han adquirido una nueva significación en el contexto nacional e internacional. Los monoteísmos han demostrado una gran capacidad de reorganización y encuentran intersticios donde pretenden hacer escuchar su voz desde la convicción de que no quieren desaparecer de los espacios de lo público. En este marco, coincidimos con el sociólogo Néstor Da Costa al sostener que en nuestro país no existe una búsqueda real por parte de la iglesia de imponer nuevamente el Estado confesional; por el contrario, se ha comprobado el aprecio generalizado hacia la separación institucional con el poder político. (Da Costa, 2006: 175) La lucha actual radica entonces en la práctica cotidiana de la integración de lo religioso en lo público como un aspecto cultural más de la identidad de los orientales.

\section{La Jura en la Matriz}

El 19 de junio de 2014 estos dos colegios "habilitados" juraron la bandera en la catedral metropolitana bajo la consigna que tradicionalmente han sustentado en las obras educativas: formar a sus estudiantes para ser "buenos católicos y virtuosos ciudadanos". Si bien el acto fue dirigido por los directores de ambas instituciones y contó con la participación de alumnos y familias, el invitado especial lo constituía el entonces Arzobispo de Montevideo, el salesiano Daniel Sturla quien realizó un discurso alusivo a la celebración. El acto que tradicionalmente se celebraba en las propias instituciones, fue trasladado a la Matriz por dos motivos: el primero, la conmemoración de los 250 años del nacimiento del José Artigas -ocurrido en Montevideo, el 19 de junio de 1764- cuyo bautismo fue realizado pocos días después en esta iglesia (que aún conserva como parte de su patrimonio histórico la piedra bautismal utilizada y el acta sacramental). El segundo motivo, consistía en que ese año se festejaban los ochenta años de la llegada de los primeros religiosos de la congregación al Uruguay. Ambas razones acompañaron la decisión de reunir a los alumnos de primer año de liceo de los colegios de la capital -la obra cuenta con instituciones educativas en otros departamentos- en una actividad en la que sus responsables entendían que los reconocía como integrantes de la grey católica y como ciudadanos del país. En este marco, también fueron proyectadas para ese día actividades lúdicas en la Plaza Independencia y palabras alusivas a la fecha realizadas por educadores de las instituciones con la estatua de Artigas como marco simbólico.

Desde ya hacía unos años, uno de los colegios venía instrumentando una serie de proyectos encaminados a generar en sus estudiantes un sentido de compromiso con algún aspecto de la realidad sociopolítica. Teniendo esta conmemoración como nodo de acciones comunitarias, se procuraba fomentar la responsabilidad de los juramentados con tareas de aula que los vincularan a la sociedad en clave de diversidad. En este sentido, en el 2011 el tema central estuvo pautado por las celebraciones 
del Bicentenario del inicio de la Revolución Oriental por lo que el foco consistió en trabajar "el país de las hazañas y el Uruguay posible”. El invitado fue Alcides Edgardo Ghiggia, autor del gol del triunfo en la final de la Copa del Mundo en Maracaná contra Brasil en 1950. En 2012 el acto contó con la presencia del Padre salesiano Mateo Méndez dado que los estudiantes abordaron la temática de "la situación de los jóvenes en nuestra sociedad, especialmente de los más carenciados" en el marco de la convocatoria por la baja de la edad de imputabilidad. El invitado respondía al foco de actividades que tenían por objeto el análisis de prácticas educativas y pastorales, así como la trayectoria del Movimiento Tacurú creado en 1981. Por su parte, en 2013 el eje transversal fue el proyecto "Instrucciones - Instituciones", por lo que el acto contó con la presencia del entonces Vicepresidente de la República, Cr. Danilo Astori. En cada uno de estas conmemoraciones, el invitado realizó un discurso relativo a la fecha y al tema en cuestión, también estuvo a su cargo la lectura del juramento que fue recibido siempre por el Director del colegio (Informe de Colegios al CES, 20/julio/2014).

\section{Las actuaciones del Consejo de Enseñanza Secundaria}

Realizado el acto, la Inspección de Institutos y Liceos Habilitados inició una investigación para la cual solicitó con fecha del 25 de junio de 2014, la comunicación por escrito acerca del lugar donde se había realizado el juramento -notificación que no se había cumplido en tiempo y forma- y la modalidad en que se había realizado la parte protocolar del mismo. Solicitadas estas declaraciones, las autoridades actuantes iniciaron un proceso por el cual se verificó la veracidad de la información y se estudió el caso. El resultado de esta investigación observó que no se atendió fehacientemente la normativa que regula el acto de la Jura de la Bandera, por este motivo observa su accionar e insta a atender la reglamentación para próximas celebraciones.

Es de orden recordar, que la Ordenanza 14 de 1994 exige a los colegios habilitados el cumplimiento de una serie de obligaciones administrativas que abarca la sistematización de la documentación acerca de sus funcionarios docentes y no docentes, la matrícula y actuación de su alumnado, así como el funcionamiento institucional. Toda esta información debe ser comunicada a la Inspección de Institutos Habilitados para su control y monitoreo. Entre estas exigencias, se destaca la obligación de informar al Consejo respectivo sobre la celebración de actos patrióticos (art. 16, inciso G) mientras especifica que el juramento deberá ser recibido por el Director del liceo (art. 25). (CES, Ordenanza 14). Para ello, esta autoridad debe cumplir con el requisito de ser docente efectivo de Enseñanza Secundaria o estar jubilado por este cargo (CES, Oficio 294 del 20/junio/2013, en cumplimiento de lo establecido en Circulares lo 2289/97 y 2670/05). 
Con este marco reglamentario, el 11 de diciembre de 2014 (día en que se conmemora la aprobación de la ley que crea Enseñanza Secundaria en 1935) el Consejo se expidió sobre lo acontecido. En su resolución entendió que debió haber sido informado sobre el cambio de lugar, aclarando que los actos patrios sólo se pueden llevar adelante afuera del edificio del instituto en caso de fuerza mayor. Sin embargo, no realiza comentarios respecto a la elección de la Matriz para tales efectos. Con respecto a la modalidad instrumentada, apuntó a que si bien fue el Director quien tomó la jura de los estudiantes en la catedral, la lectura por parte de Sturla generó "una ficción en la que uno lee y el otro recibe, lo que en sí valida el mismo para los alumnos presentes, pero no quita responsabilidad al Colegio en cuanto al claro incumplimiento de la normativa que regula dicha ceremonia" (CES, Exp. № 963/2014, 11/diciembre/2014).

De acuerdo a lo expresado, las observaciones realizadas por el CES se enmarcaron dentro de una reglamentación que comprende el acto de juramentar como una acción en la cual son los participantes del compromiso los únicos habilitados a actuar: los estudiantes de primero, y quien presenta y recibe el compromiso. En este sentido, nos preguntamos: si es la modalidad del juramento uno de los motivos que generó la observación, ¿por qué las autoridades no intervinieron en las anteriores celebraciones en las que se procedió bajo la misma modalidad? La falta de actuación de las autoridades en los años precedentes nos habilita a elaborar algunas conclusiones. Entendemos que la intervención de una relevante autoridad eclesiástica en la lectura del juramento, provocó la necesidad de proteger la "liturgia cívica" consagrada en la norma jurídica frente a los embates de una religión católica que continúa queriéndose manifestar en los actos pautados por el Estado. De esta manera, es la laicidad excluyente la que impera en la normativa institucional la que fue rebatida por los colegios en la acción, amparados éstos por el derecho de expresión de su propia religión en el ámbito público.

Es necesario destacar que en los actos institucionales de colegios confesionales se cuenta con la participación de gran parte de la comunidad educativa cuyas funciones en muchos casos abordan la catequesis, experiencias de retiro y misión, incluso en muchos de ellos se cuenta con la presencia de monjas, sacerdotes y hermanos que acompañan a los estudiantes en estas instancias de formación. Al ser comúnmente los integrantes de la comunidad de fe los que asisten a este tipo de actividades donde se pone en juego la ciudadanía católica, las familias que presenciaron el acto -que no participan unánimemente del credo- no vieron con extrañeza los cambios implementados para esta ocasión.

En este sentido, desde el colectivo institucional se comprendió que existía una separación clara en la parte protocolar por la cual se especificó que el invitado leía, pero que era responsabilidad del Director asumir el juramento - proceder realizado en anteriores celebraciones-. Así, la separación entre la parte 
secular y la confesional fue entendida por los participantes. De alguna manera, las autoridades de Secundaria atendieron a este efecto, validando el compromiso público de los estudiantes pero, a su vez juzgando que este modo de actuar difumina una delgada línea divisoria que pone en riesgo la separación legal entre Iglesia y Estado.

Así como el CES apreció irregularidades, otros actores sociales criticaron y denunciaron la actuación de estos colegios. En todos los casos se partió de la premisa de que es la patria “sacralizada" a través de la figura de su prócer-, la que se reconfigura permanentemente a través de discursos y acciones unánimemente formalizadas en el país. Son estos actos los que la reconstruyen cotidianamente en la ritualidad, aspecto fundamental para reafirmar el imaginario colectivo nacional. En ellas, es el sentido de unidad el que prima a la hora de tomar partido.

\section{Algunas resonancias}

Frente a este acto del 19 de junio, se hicieron escuchar algunas voces en repudio al lugar elegido y al invitado que hizo lectura de la fórmula juramental. Entre ellas, fue la Asociación Uruguaya de Libres Pensadores (AULP) quienes llevaron adelante los mayores embates en su contra. El 3 de julio de 2014 publicaban en las redes sociales una declaración en la que consignaban:

Es asimismo llamativo y preocupante, que ese acto se realizara en presencia del jefe de la Iglesia Católica Apostólica y Romana en la ciudad de Montevideo, Daniel Sturla y de la bandera de otro Estado - el Estado Vaticano - con el que si bien nuestro país tiene relaciones diplomáticas, se trata de una potencia extranjera, pudiendo constituir ello un acto de violación a nuestra soberanía. La ley es clara al respecto que en ese acto: por su significación los únicos símbolos presentes pueden ser los de nuestra patria. (Asociación Uruguaya de Libres Pensadores - AUPL, Declaración Pública, 3/julio/2014)

Para la AUPL el juramento realizado violentó la ley dado que se llevó a cabo en un espacio inadecuado por no contener exclusivamente símbolos patrios. Al respecto, cabe preguntarse: en los colegios cuyas denominaciones se identifican con un país determinado, ¿no tienen imágenes y símbolos de los mismos en sus instalaciones? En la propia institución de un colegio católico, protestante o judío ¿no existen imágenes y símbolos religiosos en sus salas, salones de actos o gimnasios? Toda comunidad educativa genera un carisma que define la impronta de su quehacer cotidiano y la distingue culturalmente de las demás. En la acción de esta comunidad en particular se encuentra la clara base de estar compartiendo una actividad instrumentada por el Estado para la cual se reconocen a sí mismos en su credo y ciudadanía, y desde allí abordan su compromiso con la patria. 
La concepción de laicidad asumida adquiere entonces un sentido positivo de reconocimiento público que los católicos han defendido tradicionalmente.

Esta noción de laicidad basada en la libertad de expresión pública de la fe religiosa ha sido adoptada en otros países. Ejemplo de ello, lo constituye la sentencia 101/2004 aprobada por el Tribunal Constitucional Español el 2 de junio.

En su dimensión objetiva, la libertad religiosa comporta una doble exigencia, a que se refiere el art. 16.3 CE: primero, la de neutralidad de los poderes públicos, ínsita en la aconfesionalidad del Estado; segundo, el mantenimiento de relaciones de cooperación de los poderes públicos con las diversas iglesias. En este sentido [...] “el art. 16.3 de la Constitución [...] considera el componente religioso perceptible en la sociedad española y ordena a los poderes públicos mantener las consiguientes relaciones de cooperación con la Iglesia Católica y las demás confesiones, introduciendo de este modo una idea de aconfesionalidad o laicidad positiva.

España ha establecido un régimen jurídico de convivencia religiosa encaminado a desterrar las posturas radicales. Las líneas de acción han consistido en promover el diálogo de las creencias con el Estado y de las confesiones entre sí para establecer un sistema de flexibilización basado en la escucha, la participación y la innovación. El objetivo primordial ha sido promover una identidad cultural diversa basada en una reglamentación que permita el despliegue de la libertad religiosa.

Por otro lado, el representante de la Asociación Civil 20 de Setiembre y portavoz de la Asociación Internacional de Libres Pensadores, Elbio Laxalte Terra realizaba una columna de opinión que fue publicada en laicismo.org el 18 de julio de 2014 donde, a las críticas sobre las cuestiones formales del acto, sumaba el ataque a la institución eclesiástica que, a su entender, habría pretendido sustituir al Estado: "Esta acometida de la iglesia católica uruguaya, que intenta ocupar espacio político, social y religioso, legitimado en la ofensiva evangelizadora de la era Francisco, no hace otra cosa que explotar las debilidades del sistema político". (Laxalte Terra, 18/julio/2014) Por este motivo reclamaba:

La laicidad rechaza los aspectos políticos de las religiones, y la ocupación por las mismas del espacio público que por definición es de todos los ciudadanos y ciudadanas en tanto tales y no por sus creencias y opiniones; pero les deja a ellas todas sus libertades en la vida social bajo el régimen del derecho común. (Laxalte Terra, 18/julio/2014)

Laxalte Terra parte de la concepción asimilada tradicionalmente en nuestro país, en la que "lo público" es identificado a "lo estatal". En este sentido, la diversidad religiosa aparecería como un aspecto discordante con la norma legal al manifestarse en los espacios públicos desde 1919. La idea de ciudadanía es adoptada entonces desde la uniformidad. 
El representante de esta Asociación Civil asume en su argumentación una hipótesis clásica en la historiografía nacional que ponía un límite claro entre lo que se podía expresar en lo público o estatal y en lo privado. Estas concepciones, también tuvieron una fuerte anuencia en la historiografía cristiana que afirmó que en los primeros años del Estado laico, la iglesia y su feligresía se habían transformado en un "gueto", término utilizado para definir el repliegue de los fieles sobre sí mismos. Fueron el jesuita Juan Luis Segundo y el intelectual católico Patricio Rodé, quienes sostuvieron en la década de 1960 este término para referirse a los primeros tiempos del Estado laico, etapa en la que, a su entender se instaló "una actitud de preservación de los ya católicos, encuandrándolos en estructuras confesionales, pequeña cristiandad privada enclavada en un país laicista, fortaleza sitiada". (Segundo y Rodé, 1969: 126) Esta categoría de análisis fue continuada por diversos equipos de investigación, entre los que se encuentran Gerardo Caetano y Roger Geymonat (1997), quienes trabajaron los embates secularizadores y las propuestas de organizaciones orientadas por la iglesia. Los autores señalaron el objetivo de "salvar a los salvados" de la nueva estrategia y con ello, armar un tejido de asociaciones cuya función era vivir en comunidad mientras se compartía la espiritualidad (así se crearon colegios, universidad, partido político, se organizaron conferencias, uniones y clubes, entre otros). (Caetano, Geymonat, 1997: 148)

Sin embargo, en estos últimos años, la historiadora Carolina Greising ha brindado nuevos aportes a esta interpretación. Partiendo de una concepción que no limita el espacio público al estatal, ha iniciado un nuevo camino de investigación poniendo en cuestión la idea de "gueto católico". Para ello, describió las actividades parroquiales en el marco de una permanente expansión edilicia y devocional en los barrios de la capital ocurrida desde 1919, impulsada por el nuevo Arzobispo Monseñor Francisco Aragone bajo las pautas de Roma. En su estudio, subraya las aspiraciones de continuidad en cuanto a la participación de la iglesia en las celebraciones públicas, haciendo foco en la consagración de la república al Sagrado Corazón -motivo por el cual se creó el Santuario Nacional del Cerrito de la Victoria-. Como ejemplo, consigna la aspiración obispal de entonces: “el acto conjugaría el sentimiento religioso con la devoción patriótica, ya que de esta forma la Iglesia Católica uruguaya adhería al centenario de la independencia a celebrarse el 25 de agosto de 1925, día en que se debía inaugurar el templo, denominado Santuario Nacional del Sagrado Corazón de Jesús”². (Greising, 2017: 126-127)

\footnotetext{
${ }^{2}$ Este proyecto no pudo cumplir con el cronograma inicial dadas las dimensiones de templo. Greising señala que en 1933 se finalizaron los cimientos, la planta se inauguró en 1938, mientras que la cúpula y las torres estuvieron construidas en 1946. (Greising, 2017: 132)
} 
A estas acciones de la iglesia podemos agregar la convocatoria diocesana a congregacionesreligiosas a fundar colegios para educar en la fe en diferentes barrios de Montevideo y la apuesta de algunos clérigos y laicos católicos a editar libros y manuales de historia con claras referencias a lo religioso y a la actuación pública de los miembros de sus órdenes. A su vez, en la década de 1930 la Acción Católica procuró extender la fe a través de los fieles organizados a partir de las parroquias impulsando con ello la formación del laicado y el acompañamiento clerical a instancias de Pío XI (Bazzano et al, 1993: 117-118). Comprendemos que la observación del aumento de prácticas de convivencia basadas en una ética secularizada, impulsó a los católicos a participar en los espacios públicos amparados en la libertad de cultos, con el claro objetivo de permanecer e incluso, apostar al crecimiento del número de fieles.

En cuanto a los discursos anteriores a 1919, gran parte de la iglesia se mostraba preponderantemente intolerante frente a la diversidad religiosa -situación que se ha visto reflejada en más de una opinión hasta nuestros días-. Si bien podemos citar posturas de cierta apertura al mundo moderno y sus cambios, lideradas por Mariano Soler y Juan Zorrilla de San Martín, los sectores conservadores del catolicismo fueron ganando la pelea, asumiendo cada vez más una postura romanista y antimoderna. Es esta última imagen de la iglesia la que aún sustentan los sectores anticlericales de la sociedad mientras desconocen la pluralidad de opciones políticas y sociales surgidas durante el siglo XX y que se sustentan dentro de la misma hasta la actualidad.

En su columna de opinión, Laxalte Terra agrega la dificultad que esta institución ha tenido para adaptarse a los nuevos desafíos que la actualidad le ha planteado, tales como: igualdad de género, inclusión de diversas opciones sexuales, matrimonio igualitario e interrupción voluntaria del embarazo. Al respecto, es necesario puntualizar que todos esos aspectos adquieren validez si adoptamos un concepto restringido de iglesia -entendida ésta como institución integrada por clérigos y monjas-, en donde estas conquistas sociales son rechazadas en el discurso oficial. Sin embargo, si asumimos una concepción de iglesia en sentido extendido -cual comunidad de fieles-, esta idea de falta de adaptación comienza a desactivarse por la propia diversidad de sus miembros y por las diferentes opciones y tendencias de sus colectivos.

En esta idea de iglesia sostenida por su feligresía, muchos de sus creyentes -y aún varios representantes del clero- coinciden con el concepto de laicidad de Laxalte Terra: 
condición de no imponerlas a quienes tienen otras prácticas o simplemente a quienes no desean abrazar ninguna o no les interesa. (Laxalte Terra, 18/julio/2014)

Ahora bien, la idea de base liberal que sostiene que todos los ciudadanos son individuos en condiciones igualitarias debe ser sometida a varios cuestionamientos. En nuestro caso en particular, entendemos que toda persona subjetiva la realidad en la que vive desde sus propias concepciones, y la religiosidad es una de ellas. Si comprendemos que la ciudadanía debe ser resignificada permanentemente desde la diversidad, podremos percibir la alteridad reconociendo en el "otro" a un "igual" en la "diferencia", que vive su vida y se constituye como ciudadano desde sus propias convicciones.

\section{Conclusiones}

En este artículo hemos analizado el acto patriótico que dos colegios católicos habilitados realizaron en 2014 en la catedral con la presencia del Arzobispo de Montevideo. La difusión en prensa trajo a la palestra la concepción tradicional laica basada en la neutralidad del Estado en materia religiosa y la idea elaborada a principios del siglo XX de limitar las prácticas al ámbito privado. No obstante ello, el propio acto constituyó una declaración de intención de los cristianos que tomaron la opción de ser reconocidos en su calidad de ciudadanos católicos. Por su parte, las autoridades actuantes aplicaron la ley y una reglamentación no apta a la libre interpretación. La celeridad de los comportamientos formales en este tipo de celebraciones ha sido el objetivo de las normas estatales.

En nuestro país, es preciso generar el debate acerca de la idea de laicidad a sustentar en la actualidad en la educación que nos permita generar acuerdos para sostener o reencausar este principio en constante revisión. La coexistencia de diversas religiones, incrementadas algunas de ellas por los nuevos aluviones inmigratorios, está redefiniendo el mapa religioso y plantea nuevos desafíos a la convivencia social. En este marco, consideramos que la laicidad que parte del "no decir" amparada en la neutralidad estatal o laicidad negativa, provoca que los alumnos puedan gestar imágenes tergiversadas de cualquier "otro" creyente. Coincidimos con la propuesta de Edgar Morin quien convoca a "hacer resurgir la laicidad [que implica] problematización de Dios, del mundo, de la naturaleza, del hombre, de la ciudad, de la verdad" (Morin, 2001: 110). El trabajo en el aula de la diversidad y la tolerancia son puertas de acceso a la descripción de la alteridad desde la comprensión, sin traspasar el límite de la confesionalidad.

Asimismo, comprendemos que, si bien la idea de "reconocimiento" de las religiones ha sido bandera de los católicos, no podemos dejar de observar que otros colectivos han asumido la misma consigna para dejar de ser invisibilizados. Ejemplo de ello, Julio Kronberg afirma refiriéndose al umbandismo: 
En Uruguay hay un marco legal apropiado. La Constitución garantiza la libertad y el respeto a las religiones... Llegando al tema 'pensamiento popular', lamentamos tener que decir que existe la intolerancia... la falta de conocimiento se transforma en una forma de intolerancia. (Kronberg, en: VV.AA., 2005: 163)

No obstante ello, entendemos que si bien este principio es reclamado por diversos sectores religiosos a las personas no integrantes de la comunidad de fe, no constituye una pauta unánime al interior de sus obras e instituciones educativas a donde concurren estudiantes que no son atraídos por el credo y se ven obligados a participar de los rituales religiosos. La libertad religiosa pregonada debería comenzar en sus propios institutos.

A su vez, consideramos que esta apuesta de los colectivos religiosos hacia la laicidad positiva requiere una profunda reflexión acerca de las posibilidades y limitaciones de sus expresiones. En este sentido, nos preguntamos ¿cuál debe ser el límite en el ejercicio de esta libertad religiosa? Nuestro país cuenta con el amparo de principios declarativos a favor del ejercicio de este derecho pero no posee una estructura reglamentaria que especifique los marcos de su praxis individual o colectiva en los diversos ámbitos públicos y estatales. Por ello, es necesaria la discusión interreligiosa y el entendimiento de todos los actores con el Estado para que se establezcan normas que regulen y encuadren su funcionamiento en el marco jurídico, eliminando los "vacíos" legales hoy existentes.

\section{Fuentes}

Asociación Uruguaya de Libre Pensamiento (AUPL). Declaración Pública, 3/julio/2014. Consejo de Enseñanza Secundaria, Ordenanza 14.

Consejo de Enseñanza Secundaria. Expediente $N^{\circ}$ 963/2014, 11/12/2014. Informe de Colegios al CES, 20/julio/2014.

Concilio Vaticano II, Declaración Dignitatis humanae, 7/setiembre/1965. Disponible en: http://www.vatican.va/archive/hist_councils/ii_vatican_council/documents/ Acceso: 11 de noviembre de 2018.

Laxalte Terra, Elbio. Reiteradas violaciones a la laicidad en Uruguay, Columna de opinión en: laicismo.org, 18/julio/2014. Acceso: 20 de julio de 2018.

Cardenal Daniel Sturla sbd, Homilía del 24 de diciembre de 2016, en: https://www.aciprensa.com/noticias/, 10/enero/2017. Acceso: 11 de noviembre de 2018.

\section{Referencias bibliográficas}

Bazzano et alt. (1993) Breve visión de la Historia de la Iglesia en el Uruguay. Montevideo: OBSUR

Caetano, G. et alt. (2013) El Uruguay laico. Matrices y revisiones. Montevideo: Taurus

Caetano, G. y Geymonat, R. (1997) La secularización uruguaya (1859 - 1919). Catolicismo y privatización de lo religioso. Montevideo: Taurus 
Da Costa, N. (2006) Laicidad en América Latina y Europa. Repensando lo religioso entre lo público y lo privado en el siglo XXI. Montevideo: CLAEH.

González Merlano, G. (2015) Perspectiva jurídica de la libertad religiosa y la libertad de conciencia. En: Revista de Derecho. UCUDAL, 2da. época. Año 10. N. ${ }^{\circ} 11,81-104$. Disponible en: https://revistas.ucu.edu.uy/index.php/revistadederecho/article/view/725 (Acceso: 11 de noviembre, 2018)

Greising, C. (2016) El templo de la patria en el Cerrito de la Victoria de Montevideo (Uruguay) y la devoción del Sagrado Corazón de Jesús. Desafíos de la Iglesia Católica separada, 1919-1928, en: Anuario Nº 28 pp. 119-140. Disponible en: http://anuariodehistoria.unr.edu.ar/ojs/index.php/Anuario/index. (Acceso: 25 de julio, 2018)

Morin, E. (2001) La cabeza bien puesta. Repensar la reforma. Reformar el pensamiento. Buenos Aires: Nueva Visión Segundo, L. y Rodé, P. (1969) Presencia de la iglesia, Enciclopedia Uruguaya №37: Montevideo.

Sloterdijk, P. (2011) Celo de Dios. Sobre la lucha de los tres monoteísmos. Madrid: Ediciones Siruela

VV.AA. (2005) El diálogo interreligioso en el Uruguay. Diversidades y confluencias. Montevideo: OBSUR 